\title{
STUDY OF STABILITY OF POTENTIAL BETA- ADRENOLYTICS, DERIVATIVES OF THE [(ARYLCARBONYL)OXY]AMINOPROPANOL BY KINETICS OF ALKALINE HYDROLYSIS
}

\author{
${ }^{1}$ Stankovičová, M. - ${ }^{1}$ Bezáková, Ž. - ${ }^{1}$ Pavlíková, J. - ${ }^{1}$ Mažeriková, J. - \\ ${ }^{1}$ Kissová, M. - ${ }^{2}$ Mokrý, P. $-{ }^{2}$ Csöllei, J. \\ ${ }^{1}$ Department of Pharmaceutical Chemistry, Faculty of Pharmacy, Comenius University, \\ Bratislava, Slovak Republic \\ ${ }^{2}$ Institute of Chemical Drugs, Faculty of Pharmacy, University of Veterinary and \\ Pharmaceutical Sciences, Brno, Czech Republic
}

This work deals with the study of the stability of six derivatives of the [(arylcarbonyl)oxy] amino propanol with carbamate substitution on the benzene ring. The studied compounds are different in the substitution on the amine group in the side chain as well as in the substitution on the carbamate functional group. The hydrolysis of compounds was measured in the aqueous-ethanol sodium hydroxide solution $\left(0.1\right.$ mol. $\left.1^{-1}\right)$ at $25,37,45$ and $60^{\circ} \mathrm{C}$ spectrophotometrically in the ultraviolet and visual regions. The studied compounds possess two functional groups, which undergo hydrolysis. The pseudo-first order rate constants of hydrolysis for individual reaction steps were determined. The ester functional group of compounds hydrolyses very quickly in this medium. The compounds possessing the tertiary substitution on the amino group are less stable toward alkaline hydrolysis. The course of hydrolysis of compounds was also investigated by thin layer chromatography (TLC).

Keywords: ultra short acting beta-adrenolytics - stability - kinetics of hydrolysis

\section{INTRODUCTION}

The studied compounds are derivatives of phenylcarbamic acid, with potential ultrashort beta-adrenolytic activity. The compounds were prepared at the Institute of Chemical Drugs of the University of Veterinary and Pharmaceutical Sciences Brno, Czech Republic. The ultra-short beta-adrenolytic activity of derivatives of [(arylcarbonyl)oxy]aminopropanol was attained by the incorporation of metabolically 
unstable ester functional group into the connecting chain of origin aryloxypropanolamine structure of the beta-adrenolytics. The ester functional group is more labile than ethereal connecting chain. The ester group is quickly hydrolysed by esterase, what is the case of the shortening of activity of these derivatives. These potential drugs may be indicated in supraventricular tachycardias, in fibrillations, hypertension and in acute myocardial infarction [1]. [2].

The course of hydrolysis of these compounds was previously investigated by TLC

The goal of this work is the study of kinetics of alkaline hydrolysis of the chosen compounds, derivatives of [(arylcarbonyl)oxy] aminopropanol (Table 1). Hydrolysis is the most frequent reaction in the degradation process of the esters. The studied compounds possess two functional groups, which undergo hydrolysis. In the degradation processes of compounds it is supposed that the first process is hydrolysis of the ester group. The hydrolysis of the carbamate functional group follows.

\section{MATERIALS AND METHODS}

\section{Studied compounds}

The studied compounds were synthesised as hydrochloride by the authors [1] and they are listed in Table 1. All other chemicals and solvents were of analytical reagent grade.

Table 1. List of studied compounds

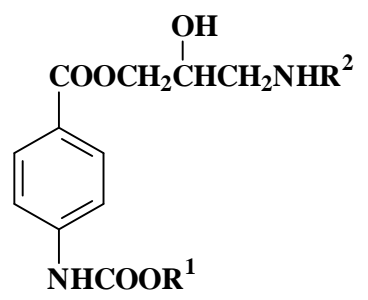

\begin{tabular}{|l|c|c|c|}
\hline Cmpd & $\mathbf{R}^{\mathbf{1}}$ & $\mathbf{R}^{\mathbf{2}}$ & $\mathbf{M}_{\mathbf{r}}$ \\
\hline $\mathbf{4 1 3}$ & $\mathrm{CH}_{3}$ & $\mathrm{CH}\left(\mathrm{CH}_{3}\right)_{2}$ & 346.81 \\
$\mathbf{4 2 3}$ & $\mathrm{C}_{2} \mathrm{H}_{5}$ & $\mathrm{CH}\left(\mathrm{CH}_{3}\right)_{2}$ & 360.84 \\
$\mathbf{4 3 3}$ & $\mathrm{C}_{3} \mathrm{H}_{7}$ & $\mathrm{CH}\left(\mathrm{CH}_{3}\right)_{2}$ & 374.87 \\
$\mathbf{4 4 3}$ & $\mathrm{C}_{4} \mathrm{H}_{9}$ & $\mathrm{CH}\left(\mathrm{CH}_{3}\right)_{2}$ & 388.90 \\
$\mathbf{4 1 4}$ & $\mathrm{CH}_{3}$ & $\mathrm{C}^{\left(\mathrm{CH}_{3}\right)_{3}}$ & 360.84 \\
$\mathbf{4 2 4}$ & $\mathrm{C}_{2} \mathrm{H}_{5}$ & $\mathrm{C}_{\left(\mathrm{CH}_{3}\right)_{3}}$ & 374.87 \\
$\mathbf{4 3 4}$ & $\mathrm{C}_{3} \mathrm{H}_{7}$ & $\mathrm{C}_{\left(\mathrm{CH}_{3}\right)_{3}}$ & 388.90 \\
$\mathbf{4 4 4}$ & $\mathrm{C}_{4} \mathrm{H}_{9}$ & $\mathrm{C}\left(\mathrm{CH}_{3}\right)_{3}$ & 402.92 \\
\hline
\end{tabular}




\section{Apparatus}

The Thermostat Memmert WB 10 (Germany), spectrophotometer Spectronic 20 D, Milton Roy (Germany) and spectrophotometer 8452 A DIODE ARRAY Hewlett Packard (USA) were used.

\section{Kinetic measurement}

Hydrolysis of studied compounds in sodium hydroxide 0.1 mol. $\mathrm{I}^{-1}$

The hydrolysis of studied compounds was carried out in aqueous-ethanol sodium hydroxide solution $0.1 \mathrm{~mol} .1^{-1}$ in closed flasks at $25.0 \pm 0.1^{\circ} \mathrm{C}, 37.0 \pm 0.1{ }^{\circ} \mathrm{C}, 45.0 \pm 0.1$ ${ }^{\circ} \mathrm{C}$ and $60.0 \pm 0.1{ }^{\circ} \mathrm{C}$. The ethanol concentration was $50 \%(\mathrm{v} / \mathrm{v})$, and the concentration of studied compounds was $1 \times 10^{-5} \mathrm{~mol}_{1} \mathrm{I}^{-1}$. The decrease of concentration of compounds by the reaction was determined spectrophotometrically in UV at $\lambda=266 \pm 2 \mathrm{~nm}$ and in the visual region using reagent 4-(dimethylamino)benzaldehyde (DBA) [3]. The rate constants $k\left[\mathrm{~s}^{-1}\right]$ of the alkaline hydrolysis were calculated using the kinetic equation of the pseudo-first order from the dependence of $\ln [b /(b-x)]=f(t)$ where $b$ is the starting molar concentration of studied compound, and $(b-x)$ is its concentration in time $t$. The values of activation energy $E_{A}$ were determined by the Arrhenius equation from the dependence of $\log k=f(1 / T)$ where $k$ is the rate constant and $T$ is the thermodynamic temperature [4].

\section{Thin layer chromatography}

The chromatographic separation of degradation products of hydrolysed compounds was carried out on silica gel layer Silufol ${ }^{\circledR}$ UV 254. The amount of $0.002 \mathrm{~g}$ of compound in $2 \mathrm{ml}$ of sodium hydroxide solution $\left(0.1\right.$ mol. $\left.1^{-1}\right)$ was kept at $25^{\circ} \mathrm{C}$ for 11 days. Five $\mu \mathrm{l}$ of solution was applied on the plate. For the chromatographic system $\mathrm{S}_{1}$ : hexane/ acetone/diethyl amine $(5.5: 3.0: 1.5 \mathrm{v} / \mathrm{v} / \mathrm{v})$, the chromatographic chamber was saturated for $1 \mathrm{~h}$. A UV light lamp Camag was used for detection. For the chromatographic system $S_{2}$ : toluene/acetone/formic acid $(60: 30: 1 \mathrm{v} / \mathrm{v} / \mathrm{v})$, the chromatographic chamber was saturated for $1 \mathrm{~h}$.

\section{RESULTS AND DISCUSSION}

The basic esters of phenylcarbamic acid undergo alkaline hydrolysis in accordance with the mechanism described by Dittert [5]. In alkaline medium these compounds are degraded to substituted aniline, basic alcohol and carbon dioxide. The degradation of studied compounds is going on as a complex (parallel) reaction (see Figure 1). The final product of alkaline hydrolysis of these compounds is 4-aminobenzoic acid (its sodium salt). 
The hydrolysis of compounds in the present work was measured in the aqueousethanol sodium hydroxide solution $\left(0.1 \mathrm{~mol} . \mathrm{l}^{-1}\right)$ at $25,37,45$ and $60^{\circ} \mathrm{C}$ spectrophotometrically in the UV region.

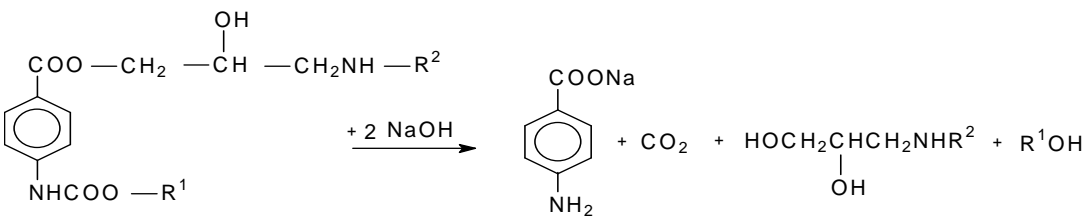

Figure 1. The course of alkaline hydrolysis of derivatives of [(arylcarbonyl)oxy]aminopropanol

Firstly we have studied the compounds 413 and 414 with the smallest substitution on the carbamate group. The alkaline hydrolysis proceeded at $21^{\circ} \mathrm{C}$ during one hour of experiment. An example of determination of the rate constant is demonstrated in Table 2.

Table 2. Determination of rate constant of compound 413 of alkaline hydrolysis at $21.0^{\circ} \mathrm{C}$

\begin{tabular}{|c|c|c|c|c|}
\hline$№$ & $\begin{array}{c}t \\
{[\mathrm{~h}]}\end{array}$ & $\begin{array}{c}A \\
\lambda=264 \mathrm{~nm}\end{array}$ & $\begin{array}{c}(b-x) \\
{\left[\mathrm{mol}^{-1} \mathrm{I}^{-1}\right]}\end{array}$ & $\begin{array}{c}\ln [b /(b-x)] \\
{\left[\mathrm{mol}^{-1} \mathrm{I}^{-1}\right]}\end{array}$ \\
\hline 1 & 0 & 0.8407 & $3.23 \times 10^{5}$ & 0 \\
2 & 0.25 & 0.8310 & $3.19 \times 10^{5}$ & 0.0116 \\
3 & 0.5 & 0.8202 & $3.15 \times 10^{5}$ & 0.0246 \\
4 & 0.75 & 0.8054 & $3.09 \times 10^{5}$ & 0.0428 \\
5 & 1 & 0.7860 & $3.02 \times 10^{5}$ & 0.0672 \\
\hline
\end{tabular}

The coefficients of the straight line are: $a_{0}=-0.0039 ; a_{l}=0.0663 ; n=5, r=0.988 ; F$ $=118.7 ; s=0.00481$. The results of determined rate constants of both compounds are in Table 3.

Table 3. Results of kinetics of alkaline hydrolysis study at $21.0^{\circ} \mathrm{C}$

\begin{tabular}{|c|c|c|}
\hline Cmpd & $\mathrm{k}^{\left[\mathrm{s}^{-1}\right]}$ & $\mathrm{t}_{1 / 2}[\mathrm{~h}]$ \\
\hline $\mathbf{4 1 3}$ & $1.84 \times 10^{-5} \pm 1.69 \times 10^{-6}$ & 10.5 \\
$\mathbf{4 1 4}$ & $2.04 \times 10^{-5} \pm 2.81 \times 10^{-7}$ & 9.5 \\
\hline
\end{tabular}

The results of hydrolysis of compounds 423, 424, 443 and 444 are in Table 4. The rate constants have been determined also in the UV region and values of activation energy $E_{A}$ were calculated. The course of hydrolysis of compound 443 at temperature $45.0^{\circ} \mathrm{C}$ determined via kinetics of pseudo-first order is depicted in Figure 2. We can see a break on the straight line. Because the studied compounds possess two functional groups which undergo hydrolysis, by this method it is possible to observe only the apparent rate constants of hydrolysis. The hydrolysis of the ester group is the rate determining process in this case. 


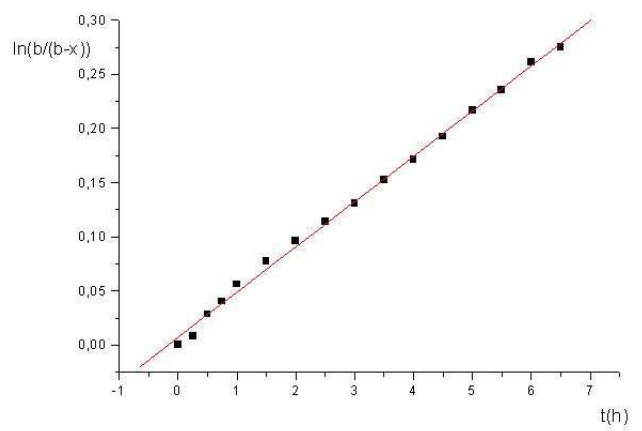

Figure 2. The course of alkaline hydrolysis of compound 443 at $45.0^{\circ} \mathrm{C}$

Table 4. Results of kinetics of alkaline hydrolysis study at $25.0^{\circ} \mathrm{C}, 45.0^{\circ} \mathrm{C}$ and at $60.0^{\circ} \mathrm{C}$

\begin{tabular}{|c|c|c|c|c|c|c|c|}
\hline \multirow[b]{2}{*}{ Cmpd } & \multicolumn{3}{|c|}{$\mathrm{k} \times 10^{6}\left[\mathrm{~s}^{-1}\right]$} & \multicolumn{3}{|c|}{$\mathrm{t}_{1 / 2}[\mathrm{~h}]$} & $E_{A}$ \\
\hline & $25.0^{\circ} \mathrm{C}$ & $45.0^{\circ} \mathrm{C}$ & $60.0^{\circ} \mathrm{C}$ & $25.0^{\circ} \mathrm{C}$ & $45.0^{\circ} \mathrm{C}$ & $60.0^{\circ} \mathrm{C}$ & $\mathrm{kJ} \cdot \mathrm{mol}^{-1}$ \\
\hline 423 & $6.17 \pm 0.27$ & $9.94 \pm 0.27$ & $14.3 \pm 0.42$ & 31 & 19 & 13.5 & $19.7 \pm 0.7$ \\
\hline 424 & $7.31 \pm 0.22$ & $12.4 \pm 0.36$ & $22.3 \pm 0.44$ & 26 & 15.5 & 8.5 & $25.9 \pm 3.9$ \\
\hline 443 & $6.53 \pm 0.21$ & $10.6 \pm 0.24$ & $15.7 \pm 0.39$ & 29.5 & 18 & 12 & $20.6 \pm 1.1$ \\
\hline 444 & $8.72 \pm 0.33$ & $13.7 \pm 0.39$ & $24.6 \pm 0.50$ & 21 & 15 & 8 & $24.0 \pm 4.5$ \\
\hline
\end{tabular}

The values of rate constants of hydrolysis indicate rise of hydrolysis rate with rise of temperature and with the branching of substitution on the amino group in the side chain as well as with the prolongation of substitution in the carbamate group. The Arrhenius plot of compound 423 is depicted in Figure 3. The values of activation energy $E_{A}$ of compounds are considerably lower than values of other basic esters of phenylcarbamic acids [6]. This indicates for preference hydrolysis of the ester group at these compounds.

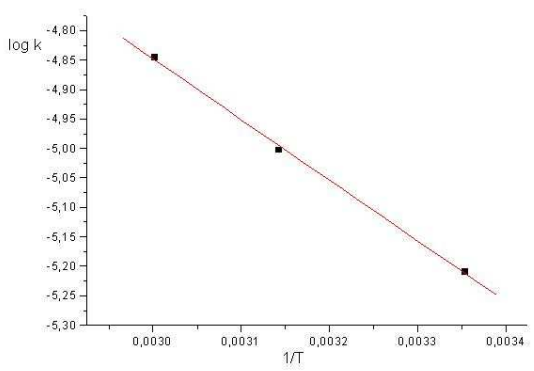

Figure 3. The Arrhenius plot of compound 423 
Table 5. The values of $\mathbf{R}_{\mathrm{f}}$ of chromatography study of alkaline hydrolysis at $25.0{ }^{\circ} \mathrm{C}$

\begin{tabular}{|c|c|c|c|c|c|}
\hline Time [days] & \multirow[t]{2}{*}{ 0 } & \multirow[t]{2}{*}{2} & \multirow[t]{2}{*}{3} & \multirow[t]{2}{*}{7} & \multirow[t]{2}{*}{11} \\
\hline Cmpd & & & & & \\
\hline \multirow[t]{2}{*}{423} & 0.30 & 0.30 & 0.03 & 0.03 & 0.03 \\
\hline & & 0.54 & 0.60 & 0.70 & \\
\hline \multirow[t]{2}{*}{443} & 0.37 & 0.39 & 0.05 & 0.04 & 0.03 \\
\hline & & 0.60 & 0.60 & 0.68 & \\
\hline \multirow[t]{2}{*}{424} & 0.38 & 0.02 & 0.04 & 0.03 & 0.03 \\
\hline & & 0.36 & 0.62 & 0.66 & \\
\hline \multirow[t]{2}{*}{444} & 0.45 & 0.02 & 0.04 & 0.03 & 0.03 \\
\hline & & 0.46 & 0.53 & & \\
\hline $\begin{array}{l}\text { 4-aminobenzoic } \\
\text { acid }\end{array}$ & 0.03 & 0.03 & 0.03 & 0.03 & 0.03 \\
\hline
\end{tabular}

The results of the chromatographic study of hydrolysis of these compounds at $25.0^{\circ} \mathrm{C}$ are in Table 5. The compounds in $2 \mathrm{ml}$ of sodium hydroxide solution $(0.1$ mol. $1^{-1}$ ) were kept at $25^{\circ} \mathrm{C}$ for 11 days, because their total hydrolysis could have been finished during this period. The degradation products of compounds 423 and 443 have been found after two days of hydrolysis. The 4-aminobenzoic acid was found after three days of hydrolysis, in the meantime the origin compound was not present. Compounds 424 and 444 degraded more quickly according to chromatography results.

The amount of the final product, the 4-aminobenzoic acid, can be determined by several procedures of visual spectrophotometry: diazotising with sodium nitrite and following copulation reaction with 1-naphthol. This reaction is not suitable for these compounds because of possible formation of the derivative of nitrosamine, which may distort the data. The reaction with 4-(dimethylamino)benzaldehyde is more suitable for determination of the 4-aminobenzoic acid spectrophotometrically in visual region at $\lambda=$ $470 \mathrm{~nm}[3]$ :

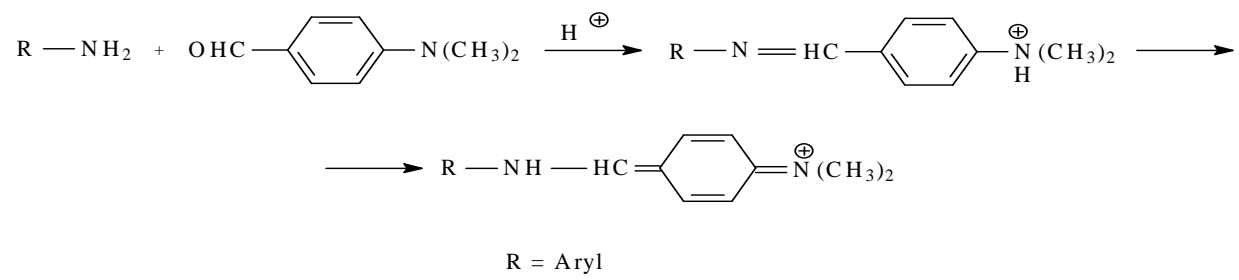

Figure 4. The course of reaction of product of hydrolysis of studied compounds with 4(dimethylamino)benzaldehyde

We have observed the hydrolysis of carbamate functional group of compounds 413 , 414,433 and 434 spectrophotometrically in the visual region by reaction with $D B A$. The values of pseudo-first order rate constants and half-lives of reaction are in Table 6 . We have conducted two parallel experiments. The results show the same hydrolysis rate for both groups of compounds. The values of activation energy $E_{A}$ for hydrolysis of the carbamate functional group are higher than for hydrolysis of the ester group but are 
lower compared with values determined for other basic esters of phenylcarbamic acids [6].

Table 6. Resultant values of rate constants of hydrolysis $k$, half lives $t_{1 / 2}$ and activation energy $E_{A}$ of compounds 413, 414, 433 and 434

\begin{tabular}{|c|c|c|c|c|c|c|c|}
\hline \multirow{2}{*}{ Cmpd } & \multicolumn{3}{|c|}{$\mathbf{k} \times \mathbf{1 0}^{\mathbf{6}}\left[\mathbf{s}^{-1}\right]$} & \multicolumn{3}{c|}{$\mathbf{t}_{1 / 2}[\mathbf{h}]$} & $\boldsymbol{E}_{\boldsymbol{A}}$ \\
\cline { 2 - 8 } & $\mathbf{3 7 . 0}^{\circ} \mathbf{C}$ & $\mathbf{4 5 . 0}^{\circ} \mathbf{C}$ & $\mathbf{6 0 . 0}^{\circ} \mathbf{C}$ & $\mathbf{3 7 . 0}^{\circ} \mathbf{C}$ & $\mathbf{4 5 . 0}^{\circ} \mathbf{C}$ & $\mathbf{6 0 . 0}^{\circ} \mathbf{C}$ & $\mathbf{k J . m o l}^{-1}$ \\
\hline $\mathbf{4 1 3}$ & $6.39 \pm 0.77$ & $13.3 \pm 0.50$ & $41.3 \pm 1.2$ & 30 & 14.5 & 4.5 & $69.5 \pm 2.0$ \\
$\mathbf{4 1 4}$ & $6.78 \pm 0.47$ & $12.4 \pm 0.50$ & $36.7 \pm 1.4$ & 28.5 & 15.5 & 5 & $63.3 \pm 0.5$ \\
& $\mathbf{2 5 . 0}^{\circ} \mathbf{C}$ & $\mathbf{4 5 . 0}^{\circ} \mathbf{C}$ & $\mathbf{6 0 . 0}^{\circ} \mathbf{C}$ & $\mathbf{2 5 . 0}^{\circ} \mathbf{C}$ & $\mathbf{4 5 . 0}^{\circ} \mathbf{C}$ & $\mathbf{6 0 . 0}^{\circ} \mathbf{C}$ & \\
$\mathbf{4 3 3}$ & $1.21 \pm 0.20$ & $3.85 \pm 0.09$ & $10.9 \pm 0.27$ & 159 & 50 & 18 & $51.5 \pm 4.3$ \\
$\mathbf{4 3 4}$ & $1.30 \pm 0.07$ & $3.69 \pm 0.07$ & $10.5 \pm 0.19$ & 138 & 52 & 18.5 & $46.9 \pm 6.4$ \\
\hline
\end{tabular}

The chromatographic separation of degradation products of hydrolysed compounds was carried out in chromatographic system $\mathrm{S}_{2}$. Table 7 shows the results of hydrolysis study in $\mathrm{NaOH} 0.1$ mol. $1^{-1}$ at $45^{\circ} \mathrm{C}$ and at $60^{\circ} \mathrm{C}$. The $\mathrm{R}_{\mathrm{f}}$ values of compound 413 and 414 are 0 , the $\mathrm{R}_{\mathrm{f}}$ value of PAB is 0.30 in this system. Both compounds besides the main product - 4-aminobenzoic acid provided several degradation products, such as 4alkoxycarbamoyloxybenzoate and 4-aminoarylcarbonyloxyaminopropanol.

Table 7. Observation of course of hydrolysis of studied compound in $\mathrm{NaOH} 0.1$ mol. $\mathrm{I}^{-1}$ chromatographically $-R_{f}$ values of hydrolysis products

\begin{tabular}{|c|c|c|c|c|c|c|c|}
\hline Cmpd & \multicolumn{3}{|c|}{413} & \multicolumn{4}{|c|}{414} \\
\hline Time [h] & $45^{\circ} \mathrm{C}$ & Time $[\mathrm{h}]$ & $60^{\circ} \mathrm{C}$ & Time $[h]$ & $45^{\circ} \mathrm{C}$ & Time $[\mathrm{h}]$ & $60^{\circ} \mathrm{C}$ \\
\hline 3 & $\begin{array}{c}0 \\
0.37\end{array}$ & 3 & $\begin{array}{c}0 \\
0.28 \\
0.44\end{array}$ & 3 & $\begin{array}{l}0 \\
0.35 \\
0.36\end{array}$ & 3 & $\begin{array}{l}0 \\
0.34 \\
0.42\end{array}$ \\
\hline 9 & $\begin{array}{c}0 \\
0.23 \\
0.40\end{array}$ & 9 & $\begin{array}{c}0 \\
0.17 \\
0.24 \\
0.36 \\
0.42\end{array}$ & 9 & $\begin{array}{l}0 \\
0.18 \\
0.37\end{array}$ & 9 & $\begin{array}{l}0 \\
0.24 \\
0.34 \\
0.41\end{array}$ \\
\hline 15 & $\begin{array}{c}0 \text { (weak) } \\
0.20 \\
0.40\end{array}$ & 18 & $\begin{array}{c}0 \text { (weak) } \\
0.21 \\
0.30 \\
0.38\end{array}$ & 15 & $\begin{array}{l}0 \text { (weak) } \\
0.16 \\
0.36 \\
0.37\end{array}$ & 18 & $\begin{array}{l}0 \text { (weak) } \\
0.10 \\
0.20 \\
0.28\end{array}$ \\
\hline 24 & $\begin{array}{l}0.16 \\
0.30 \\
0.40\end{array}$ & & 0.42 & 24 & $\begin{array}{l}0.17 \\
0.30 \\
0.37\end{array}$ & & 0.40 \\
\hline
\end{tabular}




\section{CONCLUSION}

The studied compounds possess two functional groups, which undergo hydrolysis. The pseudo-first order rate constants of hydrolysis for individual reaction steps were determined. The ester functional group of compounds hydrolyses very quickly in alkaline medium. The compounds possessing the tertial aminogroup are less stable toward alkaline hydrolysis. The TLC analysis provided 4-aminobenzoic acid as degradation product.

Acknowledgement: This study was support ed by the Grant Agency for Science of the Ministry of Education of the Slovak Republic, Grant No.1/0084/10.

\section{REFERENCES}

1. MOKRÝ P. - CSÖLLEI J. - RAČANSKÁ E. - TUMOVÁ I. - ZEMANOVÁDURMISOVÁ M.: Synthesis and study of derivatives of [(arylkarbonyl)oxy]aminopropanole, Proceedings of 54th Congress of chemical society, Brno 2002. (in Czech) Chem. Listy 96, 2002, p. 406.

2. STANKOVIČOVÁ, M. - BEZÁKOVÁ, Ž. - NIŽNANOVÁ, B.- DUDÁŠOVÁ, A. ČIERŤAŽSKÁ, D. - MAŽERIKOVÁ, J. - MOKRÝ, P. - CSÖLLEI, J.: Study of hydrolysis and stability some potential beta-adrenolytics by method of thin layer chromatography. (in Slovak) Farm. Obzor 78, (2009), p. 139-143.

3. KAKÁČ, B. - VEJDĚLEK, Z. J.: Handbuch der photometrischen Analyse organischer Verbindungen. Band 1. Verlag Chemie GmbH, Weinheim/Bergstr. 1974, p. 499.

4. TREINDL, L.: Chemical kinetics. (in Slovak) Bratislava, Slovak Pedagogical Publishing House, 1978, p. 21-22, 58-61.

5. DITTERT, L. W. - TAKERU HIGUCHI: Rates of hydrolysis of carbamate and carbonate esters in alkaline solution. J. Pharm. Sci. 52, (1963), p. 852-857.

6. STANKOVIČOVÁ, M. - ČIŽMÁRIK, J. - BACHRATÁ, M.: Kinetics of alkaline hydrolysis of basic analogues of heptacaine chloride. Chem. Papers 44, (1990), p. 171-176.

Registered: March 21, 2011

Accepted:May10, 2011
Doc. RNDr. Mária Stankovičová, CSc.

Faculty of Pharmacy

Comenius University

Odbojárov 10

83232 Bratislava

Slovak Republic

StankovicM@fpharm.uniba.sk 


\title{
ŠTÚDIUM STABILITY POTENCIÁLNYCH BETA-ADRENOLYTÍK, DERIVÁTOV [(ARYLKARBONYL)OXY]AMÍNOPROPANOLU KINETIKOU ALKALICKEJ HYDROLÝZY
}

\author{
${ }^{1}$ Stankovičová, M. - ${ }^{1}$ Bezáková, Ž. - ${ }^{I}$ Pavlíková, J. $-{ }^{1}$ Mažeriková, J. $-{ }^{1}$ Kissová, M. $-{ }^{2}$ Mokrý, \\ P. $-{ }^{2}$ Csöllei, J. \\ ${ }^{1}$ Katedra farmaceutickej chémie, Farmaceutická fakulta, Univerzita Komenského, Bratislava, \\ ${ }^{2}$ Ústav chemických liečiv, Farmaceutická fakulta, Veterinárna a farmaceutická univerzita, Brno, \\ Česká republika
}

Práca sa zaoberá štúdiom stability šiestich derivátov [(arylkarbonyl)oxy]amínopropanolu s karbamátovou substitúciou na benzénovom kruhu. Študované látky sú rôzne substituované na amino skupine v bočnom ret’azci, ako aj na karbamátovej funkčnej skupine. Hydrolýzu látok sme merali vo vodno-etanolovom roztoku hydroxidu sodného $\left(0,1 \mathrm{~mol}^{-1}{ }^{-1}\right)$ pri teplote $25,37,45$ a 60 ${ }^{\circ} \mathrm{C}$ spektrofotometrickou metódou v ultrafialovej a viditel'nej oblasti. Śtudované látky majú dve funkčné skupiny, ktoré podliehajú hydrolýze. Stanovili sme rýchlostné konštanty hydrolýzy pseudo-prvého poriadku pre jednotlivé reakcie. Esterová funkčná skupina podlieha hydrolýze vel'mi rýchlo. Látky s terciárnym substituentom na amino skupine sú menej stabilné voči alkalickej hydrolýze. Priebeh hydrolýzy látok sme sledovali aj chromatografiou na tenkej vrstve.

Acta Facult. Pharm. Univ. Comenianae 58, 2011, p. 72 - 80. 